\begin{tabular}{|l|l|l|}
\hline \multicolumn{2}{|c|}{ PublisherInfo } \\
\hline \hline PublisherName & $:$ & BioMed Central \\
\hline \hline PublisherLocation & $:$ & London \\
\hline \hline PublisherImprintName & $:$ & BioMed Central \\
\hline \hline
\end{tabular}

\title{
Proliferation organizes specification
}

\begin{tabular}{|l|c|l||}
\hline \multicolumn{2}{|c|}{ ArticleInfo } \\
\hline \hline ArticleID & $:$ & 4810 \\
\hline \hline ArticleDOI & $:$ & $10.1186 /$ gb-spotlight-20030711-01 \\
\hline \hline ArticleCitationID & $:$ & spotlight-20030711-01 \\
\hline \hline ArticleSequenceNumber & $:$ & 162 \\
\hline \hline ArticleCategory & $:$ & Research news \\
\hline ArticleFirstPage & $:$ & 1 \\
\hline \hline ArticleLastPage & $:$ & 2 \\
\hline \hline & & RegistrationDate : 2003-7-11 \\
\hline ArticleHistory & $:$ & OnlineDate \\
\hline \hline ArticleCopyright & $:$ & BioMed Central Ltd2003-7-11 \\
\hline \hline ArticleGrants & $:$ & \\
\hline \hline ArticleContext & $:$ & 130594411 \\
\hline \hline
\end{tabular}




\section{Cathy Holding}

Email: cholding@hgmp.mrc.ac.uk

Hox genes are a group of approximately 40 genes that control the anterior-posterior axial development in all animals that show such polarity. Much interest surrounds the precise regulation of this complex patterning, which depends inter alia upon qualitative and quantitative differences in Hox gene product levels in different tissues at different times. The expression pattern of this group of genes is described as temporal colinearity - genes are expressed in time in the same order that they appear on the genome - but the mechanism by which this transcription ordering is achieved has been unclear. In the July 15 EMBO Journal, Daniel Fisher and Marcel Mechali at the Centre National de la Recherche Scientifique, confirm that cellular proliferation has a primary role in the co-ordinated expression of the HoxB group of genes in two distinct systems, and demonstrate that the situation applies not only to Drosophila but to all vertebrates (The EMBO Journal, 22:3737-3748 July 15, 2003).

Fisher and Mechali completely inhibited DNA replication at various precise time points during Xenopus embryo development, and during culture of synchronized mouse embryonal carcinoma cell line P19, and measured HoxB gene group members' expression by RT-PCR. They showed that the HoxB genes are expressed in a replication-dependent manner, that their induction requires at least one cell cycle including $\mathrm{S}$ phase, and that the entire locus is activated within one cell cycle. Based on these observations they propose that during DNA replication, chromatin remodeling "licenses" the locus for later transcriptional regulation.

"Co-linearity might be achieved by two component steps: regulated derepression of the locus by DNA replication, making it permissive to regulated expression of specific transcription factors. The spatial and temporal organization of proliferation could provide a template for developmental gene expression in which staggered DNA replication along a developing axis relieves gene expression from transcriptional silencing," conclude the authors.

\section{References}

1. Vertebrate Hox gene regulation: clustering and/or colinearity?

2. The EMBO Journal, [http://emboj.oupjournals.org]

3. Centre National de la Recherche Scientifique, [http://www.cnrs.fr/index.html] 